5. Cappell MS. Spatial clustering of simultaneous nonhereditary gastrointestinal angiodysplasia. Small but significant correlation between nonhereditary colonic and upper gastrointestinal angiodysplasia. Dig Dis Sci 1992: 37: 1072-7.

6. Melve GK, Hervig T, Øvrebøe R et al. Blodtransfusjon og pretransfusjonsutgreiing ved autoimmun hemolytisk anemi av varmetype. Tidsskr Nor Lægeforen 2004; 124: 2918-20.
7. Andersen MR, Aaseby J. Somatostatin in the treat ment of gastrointestinal bleeding caused by angiodysplasia. Scand J Gastroenterol 1996; 31: 1037-9.

8. Boesby L, Christensen NJ, Kristensen L $\varnothing$. Behandling av gastrointestinal blødning fra angiodysplasier med somatostatinanalogen octreotid. Ugeskr Laeger 2008; 11: 958

9. Weiss G, Goodnough LT. Anemia of chronic disease. N Engl J Med 2005; 352: 1011-23.
10. Barkin JS, Ross BS. Medical therapy for chronic gastrointestinal bleeding of obscure origin. Am J Gastroenterol 1998; 93: 1250-4.

Mottatt 3.1. 2011, første revisjon innsendt 27.5. 2011, godkjent 26.1. 2012. Medisinsk redaktør Siri Lunde.

\title{
Kommentar
}

\section{Flere sykdommer med samme kliniske presentasjon}

Hos pasienter som har flere udiagnostiserte sykdommer samtidig, kan diagnostikken være vanskelig. Dersom symptomer og funn ved disse sykdommene er identiske eller overlapper, blir utfordringen ekstra stor. Svein-Oskar Frigstad og medforfattere gir en lærerik beskrivelse av en slik situasjon. De omtaler en person med to sykdommer: autoimmun hemolytisk anemi av varmeantistofftype og kronisk autoimmun hepatitt. $\mathrm{Da}$ hun på ny utviklet sykdom med anemi som klinisk presentasjon, var det nærliggende å tenke på eksaserbasjon av den autoimmune hemolysen. Det forelå imidlertid en tredje tilstand, blødning fra angiodysplasi, og riktig diagnose førte til at pasienten fikk virksom behandling.

Flere sykdommer hos samme pasient kan skyldes tilfeldigheter (koinsidens), assosiasjon (gjerne pga. felles årsak eller risikofaktorer) eller direkte kausal sammenheng (der den ene sykdommen fører til en eller flere andre). Klinikeren bør mistenke flere samtidige sykdommer ved symptomer og funn som ikke lett forklares av den tilstanden man påviser først.

Ved autoimmun hemolytisk anemi er det avgjørende for riktig behandling å kartlegge undergruppe og eventuell assosiert sykdom (1-3). Varmeantistoffmediert autoimmun hemolyse er en polyklonal autoimmun sykdom, dvs. en tilstand der de patogene lymfocyttene ikke tilhører én enkelt celleklon med ensartede geno- og fenotypiske karakteristika. Polyklonale autoimmune sykdommer er hyppig assosiert med hverandre, og ca. $50 \%$ av pasienter med autoimmun hemolytisk anemi av varmeantistofftype har en annen autoimmun eller lymfoproliferativ tilstand i tillegg $(1,2)$. En T-cellemediert, generell immundysfunksjon med suboptimal diskri- minering mellom «selv» og «ikke-selv» antas å ligge til grunn for utvikling av polyklonale autoimmune sykdommer (4). Kronisk lymfatisk leukemi er den sykdommen som hyppigst er forbundet med varmeantistoffmediert hemolyse, men en lang rekke andre assosierte tilstander forekommer, blant annet kronisk autoimmun hepatitt $(1,2)$.

Et mindretall av autoimmune sykdommer er monoklonale, slik som kronisk kuldeagglutininsykdom $(1,3)$ og perifer nevropati ved Waldenströms makroglobulinemi og andre monoklonale IgM-gammopatier (5). Ved slike tilstander blir autoantistoffet produsert direkte av den patologiske B-lymfocyttklonen, og pasienten har ikke noen generell autoimmun disposisjon. Nærmere immunpatologisk karakterisering av den tilgrunnliggende lymfoproliferative tilstanden kan ha differensialdiagnostisk betydning og terapeutiske konsekvenser $(1,3)$. Også polyklonale autoimmune sykdommer kan være forbundet med monoklonale lymfoproliferative tilstander. Assosiasjonen mellom varmeantistoffbetinget autoimmun hemolytisk anemi og kronisk lymfatisk leukemi er allerede nevnt. Flere autoimmune sykdommer er forbundet med økt risiko for non-Hodgkins lymfomer, og risikoen for marginalsonelymfom i glandula parotis er av enkelte forfattere funnet å være inntil 1000 ganger høyere hos pasienter med Sjögrens syndrom enn i normalbefolkningen (6).

Noen store sykdomsgrupper, slik som arteriosklerose, diabetes og lipidforstyrrelser, er så nært knyttet til hverandre at assosiasjonen er velkjent for alle leger. Når to eller flere sjeldnere, autoimmune sykdommer forekommer samtidig, kreves det at klinikeren kjenner til assosiasjonene mellom disse til- standene og bevisst tenker på dem. Kompliseres vurderingen ytterligere av en urelatert sykdom, står legen overfor enda større krav til kunnskap og klinisk årvåkenhet.

\section{Sigbjørn Berentsen}

sigbjorn.berentsen@haugnett.no

Medisinsk klinikk

Haugesund sjukehus

Sigbjørn Berentsen (f. 1948) er dr.med. og spesialist $\mathrm{i}$ indremedisin. Han er seksjonsoverlege ved Medisinsk klinikk, Haugesund sjukehus, fagansvarlig for blodsykdommer i Helse Fonna og førsteamanuensis ved Universitetet i Bergen. Forfatter har fylt ut ICMJE-skjemaet og oppgir ingen interessekonflikter.

Litteratur

1. Berentsen S, Sundic T, Hervig T et al. Autoimmun hemolytisk anemi. Tidsskr Nor Legeforen 2009; 129: 2226-31.

2. Michel M. Classification and therapeutic approaches in autoimmune hemolytic anemia: an update. Expert Rev Hematol 2011; 4: 607-18.

3. Berentsen S, Tjønnfjord GE. Diagnosis and treatment of cold agglutinin mediated autoimmune hemolytic anemia. Blood Rev 2012. e-publisert 11.2.2012. (doi: 10.1016/j.blre.2012.01.002).

4. Ward FJ, Hall AM, Cairns LS et al. Clonal regulatory $T$ cells specific for a red blood cell autoantigen in human autoimmune hemolytic anemia. Blood 2008: 111: 680-7.

5. Nobile-Orazio E. Antigenic determinants in IgM paraprotein-related neuropathies. Clin Lymphoma Myeloma 2009; 9: 107-9.

6. Smedby KE, Askling J, Mariette X et al. Autoimmune and inflammatory disorders and risk of malignant lymphomas-an update. J Intern Med 2008; 264: 514-27.

Mottatt 19.2. 2012, første revisjon innsendt 24.2 2012, godkjent 27.2. 2012. Medisinsk redaktør Siri Lunde. 